\title{
Evaluation of the analytical performance of two vitamin D immunoassay methods
}

\author{
Ozgur Mehmet Yis', , Guler Bugdayci', Rabia Nur Yildiz², Hamdi Oguzman'
}

'Department of Biochemistry, Bolu Abant Izzet Baysal University, Faculty of Medicine, Bolu, Turkey

${ }^{2}$ Department of Biochemistry, Bolu Izzet Baysal State Hospital, Bolu, Turkey

\begin{abstract}
Objectives: The increasing clinical significance of 25-hydroxyvitamin $\mathrm{D}[25(\mathrm{OH}) \mathrm{D}]$ has made it an indispensable test in the laboratory. The aim of this study was to investigate the analytical performance of 2 widely used immunoassay methods, the new Abbott Architect 5P02 25-OH Vitamin D assay (Abbott Laboratories, Lake Bluff, IL, USA) and the Beckman Coulter product, the Access $25(\mathrm{OH})$ Vitamin D Total assay (Beckman Coulter, Inc., Brea, CA, USA).

Methods: A total of 96 serum samples were used to compare the accuracy, linearity, limit of blank, limit of detection, limit of quantification, and precision of the 2 tests using the Architect i2000SR System (Abbott Laboratories, Lake Bluff, $\mathrm{IL}$, USA) and the Access2 (Beckman Coulter, Brea, CA, USA) immunoassay platform. Deming regression analysis and Bland Altman graphs were used to compare the 2 methods.

Results: The within-run coefficient of variation (CV\%) of the Architect and the Access systems was $<3.1 \%$ and $<6.72 \%$, respectively. There was good linearity of the $25(\mathrm{OH}) \mathrm{D}$ measurement at $98.9-114 \%$ for the Architect assay and $94.1-$ $103.5 \%$ for the Access assay at concentrations of $5-160 \mathrm{ng} / \mathrm{mL}$ and $6.2-210.4 \mathrm{ng} / \mathrm{mL}$, respectively. The correlation coefficient was 0.921 ( $\mathrm{y}=-2.1+0.97 \mathrm{x})$.

Conclusion: Thorough testing indicated that the new 5P02 Abbott Architect 25(OH)D and the Beckman Coulter Access2 25(OH)D Total test demonstrated appropriate analytical performance.
\end{abstract}

Keywords: Immunoassay, method comparison, vitamin D

$\mathrm{V}$ tamin $\mathrm{D}$ is a regulatory, bone-stimulating vitamin that has a role in the absorption of calcium and inorganic phosphorus from the intestine. A deficiency is known to be a risk factor for osteoporosis [1]. The importance of vitamin D deficiency in many chronic diseases, including cancer, diabetes, hypertension, and asthma, as well as bone, liver, and kidney diseases has also been demonstrated in recent studies $[2,3]$. This has increased the demand for a 25-hydroxyvitamin D [25(OH)D] test as a routine measurement in clinical laboratories [4].

Among the analytical techniques used in vitamin D measurement are a radioimmune assay, enzyme-linked immunosorbent assay, chemiluminescence immunoassay, and chemiluminescence microparticle immunoassay methods, including a competitive immunoassay, competitive protein-binding measurement, non-immunological high performance liquid chromatography performed directly after chromatographic separation, and liquid chromatography using tandem-mass spectrometry (LC-MS/MS) [5].

The poor antibody selectivity of immunoassay methods results in significant differences in various $25(\mathrm{OH}) \mathrm{D}$ measurements through cross-reaction with other vitamin $D$ metabolites, as well as serum matrix components, such as lipids [6, 7]. In recent years there has been discussion of reference methods and reference standards to improve the quality of $25(\mathrm{OH})$ $D$ testing [3]. Standardization of the $25(\mathrm{OH}) \mathrm{D}$ test is a global problem [8]. The Architect 5P02 25(OH)D test (Abbott Labo-

Address for correspondence: Ozgur Mehmet Yis, MD. Department of Biochemistry, Bolu Abant Izzet Baysal University, Faculty of Medicine, Bolu, Turkey Phone: +90 37425410 00-3028 E-mail: dromyis@gmail.com ORCID: 0000-0002-7006-3125

Submitted Date: July 12, 2019 Accepted Date: August 17, 2019 Available Online Date: October 09, 2019

${ }^{\circ}$ Copyright 2019 by International Journal of Medical Biochemistry - Available online at www.internationalbiochemistry.com

OPEN ACCESS This work is licensed under a Creative Commons Attribution-NonCommercial 4.0 International License. 
ratories, Lake Bluff, IL, USA) is a chemiluminescent microparticle immunological assay. The Access $25(\mathrm{OH}) \mathrm{D}$ Total assay is defined as a chemiluminescence immunoassay. Both of these methods are widely used in the assessment of vitamin $D$ sufficiency [9].

The objective of this study was to evaluate the $25(\mathrm{OH}) \mathrm{D}$ analytical capability of these 2 assays using the Architect i2000SR System (Abbott Laboratories, Lake Bluff, IL, USA) and the Access2 platform (Beckman Coulter, Brea, CA, USA).

\section{Materials and Methods}

Patients admitted to the polyclinics of a single hospital during 5 consecutive days were evaluated for inclusion in the present study. Adults ( $>18$ years) who were not hospitalized and who had glucose, urea, creatinine, aspartate aminotransferase, and alanine aminotransferase laboratory results that were within normal limits were selected. All of the procedures applied were performed in accordance with the ethical standards of committees on human trials (institutional and national) and the Declaration of Helsinki. The clinical research ethics committee of our region (Bolu Abant Izzet Baysal University Clinical Research Ethics Committee) approved this study on March 13, 2019 (no: 2019/97). Blood samples were drawn from the antecubital vein after overnight fasting into serum separation tubes $(5 \mathrm{~mL} B D$ Vacutainer SST II Advance Plus blood collection tubes; Becton, Dickinson and Company, Franklin Lakes, NJ, USA). After the samples were centrifuged at $1250 \mathrm{~g}$ at $+4^{\circ} \mathrm{C}$, they were aliquoted within 1 hour and measured using the Architect and Access automated immunoassay methods. Both automated immunoassay tests were performed within the same day. All of the analysis was performed according to the evaluation protocols of the Clinical Laboratory Standards Institute (CLSI) specific to the parameter.

\section{5(OH)D measurement}

The performance characteristics for the Access and the Architect systems were obtained from the respective manufacturer's instructions. The Architect analyzer instructions provide a within-run coefficient of variation (CV\%) for concentrations of $20.0 \mathrm{ng} / \mathrm{mL}, 40.2 \mathrm{ng} / \mathrm{mL}$, and $78.3 \mathrm{ng} / \mathrm{mL}$ of $2.2 \%, 2.1 \%$, and $2.21 \%$, respectively, and $3.0 \%, 3.1 \%$, and $4.1 \%$, respectively as within-laboratory (total) CV\% references. The Access manual provides a within-run CV\% of $2.2 \%, 2.1 \%$, and $1.5 \%$ at a concentration of $24.6 \mathrm{ng} / \mathrm{mL}, 49.8 \mathrm{ng} / \mathrm{mL}$, and $110.5 \mathrm{ng} / \mathrm{mL}$, respectively, and cited and $7.5 \%, 7.3 \%$, and $6.8 \%$ as within-laboratory (total) CV\% references.

\section{Analytical performance studies Accuracy}

Six samples from the Association of Clinical Biochemistry Experts External Quality Control (KBUDEK) 2018 immunoassay $13^{\text {th }}$ report period were used to evaluate accuracy. The third, fourth, fifth, sixth, seventh, and eighth samples were analyzed using both methods. Percentage differences from the published target average were calculated using the formula of $=$ (measured result-average)/average ${ }^{*} 100$ [3]. The results obtained were averaged for evaluation of total effect and bias. KBUDEK determined an acceptable accuracy percentage of $<25 \%$.

\section{Precision}

Precision data used in the study were calculated by the authors, rather than using the precision data provided by Abbott and Beckman. Precision was estimated using mean and standard deviation (SD) values obtained from repeated successive and intermittent within-run and between-run measurements. The between-day variation was calculated using mean and SD values obtained from internal quality control data.

Architect 25(OH)D internal quality control products (Multichem IA Plus, Ref: 05P76-10, Lot: 37104170; Technopath Clinical Diagnostics, Ballina Ireland) were used for Architect precision studies. Concentrations of $14.35 \pm 0.35 \mathrm{ng} / \mathrm{mL}$, $21.25 \pm 4.25 \mathrm{ng} / \mathrm{mL}$, and $34.55 \pm 6.95 \mathrm{ng} / \mathrm{mL}$ were measured 20 consecutive times in order to determine within-run precision. The 3 concentrations of internal quality control products were also studied intermittently 20 times during the day to determine the between-run precision. For between-day precision, the 3 levels of internal quality controls were analyzed using the same lot of reagents in a single device for 20 days [3].

Access $25(\mathrm{OH}) \mathrm{D}$ internal quality control products (Autonorm Lyo L-1, Ref: 212405, Lot:1608805 and Autonorm Lyo L-2, Ref: 212505, Lot:1609806; AB Scientific, London, England) were used for Access precision studies. Two concentrations of $21.5 \pm 6.5 \mathrm{ng} / \mathrm{mL}$ and $45 \pm 10 \mathrm{ng} / \mathrm{mL}$ were studied for 20 consecutive runs to determine the within-run precision. These 2 levels of internal quality controls were also studied intermittently 20 times during the day to determine the between-run precision. Between-day precision was determined using the same lot of reagents in a single device for 20 days.

All of the measurements were run according to the manufacturer's instructions.

\section{Limit of blank, limit of detection, limit of quantification}

CLSI evaluation guideline EP17-A2 was observed while performing the assessments. The zero calibrator of the limit of blank (LoB) producers was determined by conducting the analysis 20 times and calculated using the formula of $\mathrm{LoB}=$ Mean (blank)+1.645*SD (blank). The smallest non-zero calibrator of the limit of detection (LoD) was determined using a low concentration sample prepared with $1 / 2$ dilution, and was calculated using the formula of $\mathrm{LoD}=\mathrm{LoB}+1.645 * \mathrm{SD}$ (low concentration sample). The limit of quantification (LoQ) was 
determined using samples that were prepared at a concentration close to the limit specified by the manufacturer and the LoQ was established as the values with a CV limit of $\leq 20 \%[3]$.

\section{Linearity}

The highest calibrator of each kit was prepared at 6 different concentrations and each concentration was analyzed 3 times. Standards were prepared for the Architect assay at concentrations of $5-160 \mathrm{ng} / \mathrm{mL}$ and for the Access assay at concentrations of 3.1-210.4 ng/mL. Linearity was evaluated by taking the average of the concentrations studied 3 times and the degree of conformity was determined. Acceptable recovery was defined as $\pm 15 \%$ from the target concentration [3].

\section{Method comparison}

Method comparison studies were performed according to the CLSI EP 9 guideline. A total of 96 serum samples were analyzed using $25(\mathrm{OH}) \mathrm{D}$ analyte concentrations that were within the measurement limits of the Architect and Access assays [3].

\section{Statistical analysis}

Data analysis was performed using the SPSS Statistics for Windows program (version 17.0; SPSS Inc., Chicago, IL, USA). The distribution of the data was examined using the KolmogorovSmirnov test, and the parameters with normal distribution were expressed as mean $\pm S D$. Deming regression analysis and Bland-Altman plots were used to compare the 2 systems.
Bland-Altman graphs were prepared to calculate $95 \%$ limits of the inter-method relationship and the bias between averages. The coefficient of correlation between measurements was calculated. The CV\% was calculated using the manufacturer's internal quality control materials. Bias was calculated as the systematic difference between the averages of the results obtained by KBUDEK and the averages of our test results $[10,11]$.

\section{Results}

Performance characteristic measurements and 25(OH)D repeatability values with the Architect and Access internal quality controls are presented in Table 1.

In the Architect 25(OH)D measurements, linearity was demonstrated to be within the appropriate limits with $98.9-114 \%$ conformity at concentrations of $5-160 \mathrm{ng} / \mathrm{mL}$. The Access results also demonstrated linearity within the appropriate limits with $94.1-103.5 \%$ conformity at concentrations of $6.2-210.4$ $\mathrm{ng} / \mathrm{mL}$ (Fig. 1).

The mean, SD, and median values of the 96 serum samples used for method comparison were $17.63 \mathrm{ng} / \mathrm{mL}, 10.17$, and $16 \mathrm{ng} / \mathrm{mL}(2.7-41.0 \mathrm{ng} / \mathrm{mL})$ for the Architect system and 20.50 $\mathrm{ng} / \mathrm{mL}, 9.94$, and $20.13 \mathrm{ng} / \mathrm{mL}(4.47-47.73 \mathrm{ng} / \mathrm{mL})$ for the Access platform. The Architect within-run, between-run, and between-day variability coefficient (CV\%) was $<3.54 \%$. The within-run, between-run, and between-day CV\% for the Access assay was $<13.9 \%$. Deming regression analysis yielded a correlation coefficient of $r=0.921(y=-2.1+0.97 x)$ and the mean bias was $-16.32 \%$. Deming regression graphs and Bland-Altman plots are presented in Figure 2.

Table 1. $25(\mathrm{OH}) \mathrm{D}$ performance characteristics

\begin{tabular}{|c|c|c|c|c|}
\hline \multicolumn{3}{|c|}{ Performance criteria } & $\begin{array}{l}\text { Architect } \\
-0.07\end{array}$ & $\begin{array}{l}\text { Access } \\
1.67\end{array}$ \\
\hline $\mathrm{LoB}(\mathrm{ng} / \mathrm{mL})$ & & & 1.87 & 1.55 \\
\hline LoQ (ng/mL) & & & 3.0 & 4.0 \\
\hline Linearity & (ng/mL) & & $5-160$ & $6.2-210.4$ \\
\hline & & Mean & $(15.46-22.7-36.65)^{+}$ & $(16.07-39.68)^{*}$ \\
\hline & & CV \% & $(3.1-2.48-1.71)^{+}$ & $(6.72-6.17)^{*}$ \\
\hline & Between-run & SD & $(0.25-0.47-0.76)^{+}$ & $(2.91-2.71)^{*}$ \\
\hline & & Mean & $(14.5-22.03-36.21)^{+}$ & $(20.95-48.1)^{*}$ \\
\hline & & CV \% & $(1.73-2.17-2.1)^{+}$ & $(13.9-5.63)^{*}$ \\
\hline
\end{tabular}

${ }^{+}$Architect 25(OH)D internal quality controls: MultichemIA Plus, Ref: 05P76-10, Lot: 37104170; Technopath Clinical Diagnostics, Ballina Ireland. (14.35 \pm 0.35 ng/mL - $21.25 \pm 4.25$ $\mathrm{ng} / \mathrm{mL}-34.55 \pm 6.95 \mathrm{ng} / \mathrm{mL}$ ). Architect assay system (Abbott Laboratories, Lake Bluff, IL, USA). *Access 25(OH)D internal quality controls: Autonorm Lyo L-1, Ref: 212405 , Lot:1608805 and Autonorm Lyo L-2, Ref: 212505, Lot:1609806; AB Scientific, London, England. (21.5 $\pm 6.5 \mathrm{ng} / \mathrm{mL}-45.0 \pm 10.0 \mathrm{ng} / \mathrm{mL}$ ). Access assay system (Beckman Coulter, Brea, CA, USA). CV: Coefficient of variation; KBUDEK: Association of Clinical Biochemistry Experts External Quality Control; LoB: Limit of blank; LoD: Limit of detection; LoQ: Limit of quantification. 


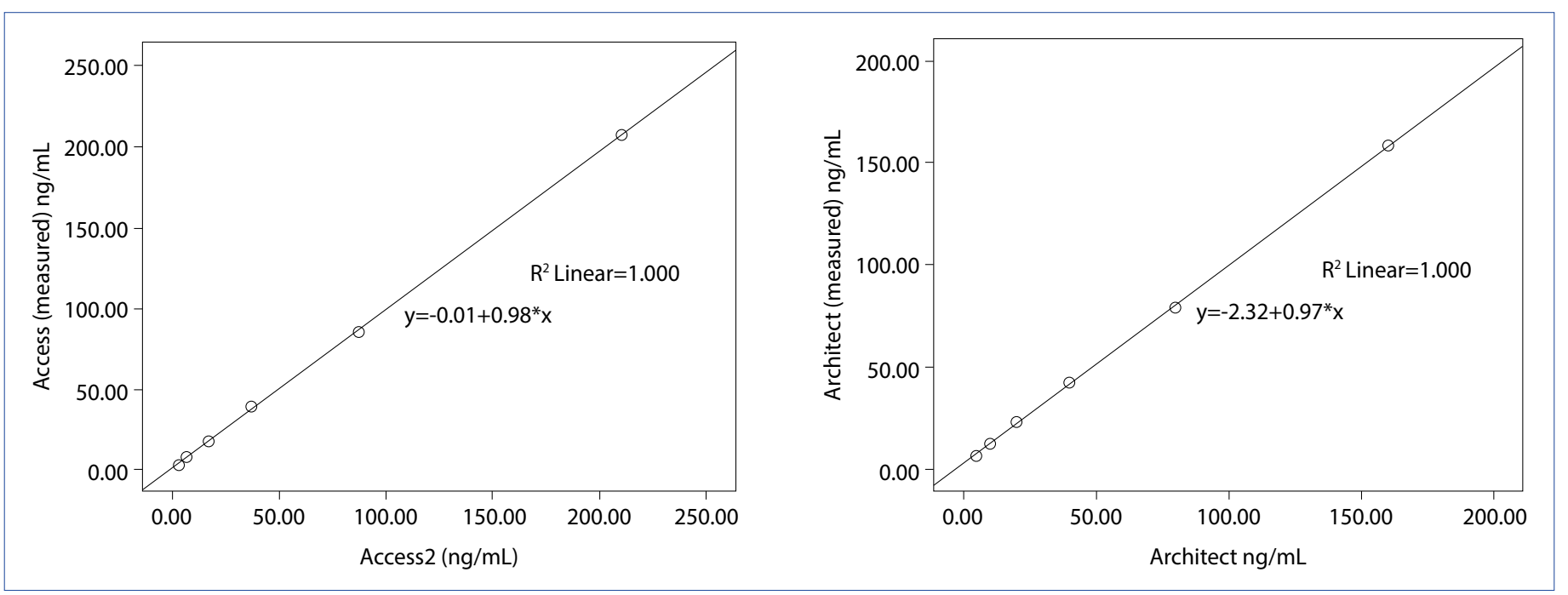

Figure 1. Linearity of the Access (Beckman Coulter, Brea, CA, USA) and Architect (Abbott Laboratories, Lake Bluff, IL, USA) 25(OH)D measurements.
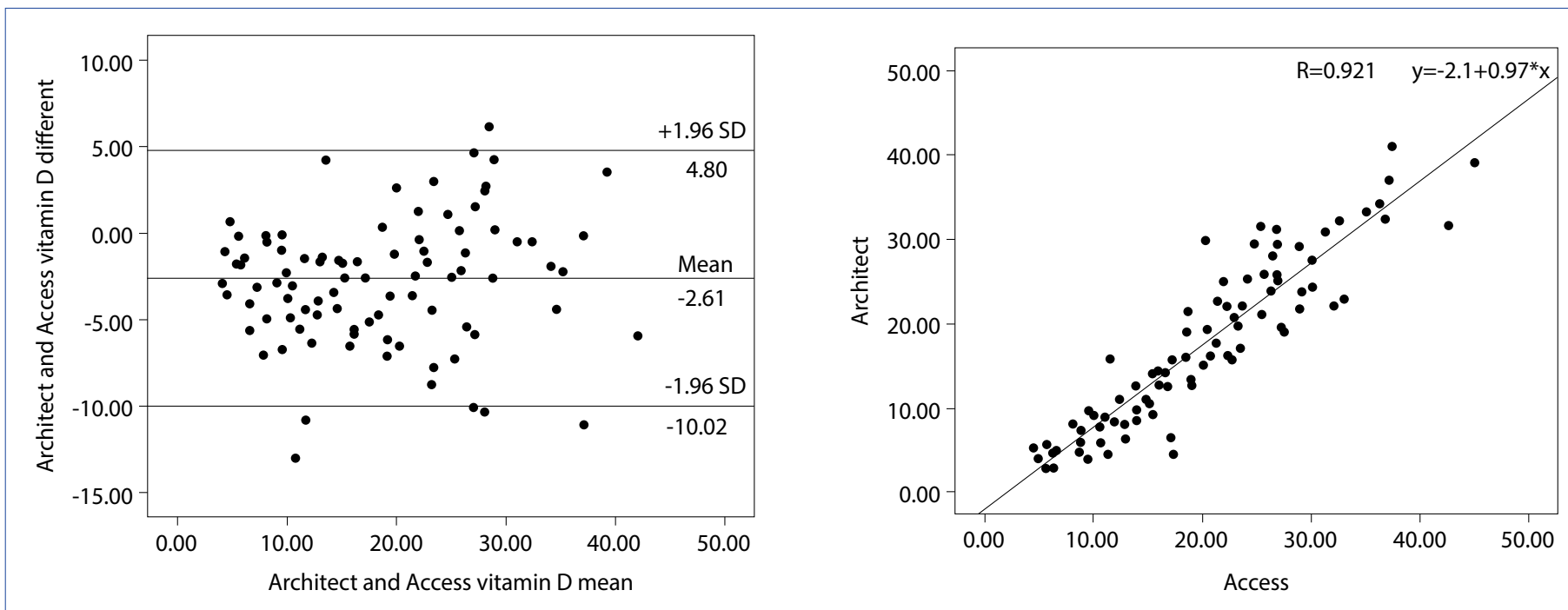

Figure 2. Regression and Bland-Altman graphs of Access (Beckman Coulter, Brea, CA, USA) and Architect (Abbott Laboratories, Lake Bluff, IL, USA) $25(\mathrm{OH}) \mathrm{D}$ measurement comparisons.

\section{Discussion}

The 25(OH)D tests measured using the Architect i2000SR system and the Access 2 system, which are commonly used immunoassay systems in routine laboratories, performed well in accuracy, LoB, LoD, LoQ, and linearity studies. Repeatability values were acceptable for both methods (Architect: $<10 \%$; Access: $\leq 15 \%)$. Accuracy was acceptable for both methods based on KBUDEK criteria ( $\leq 25 \%)$. Our method comparison study generated a correlation coefficient $r$ value of 0.921 (intercept: -2.1 [-3.94, -0.258]; slope: 0.97 [0.889, 1.058]) and a mean bias value of $-16.32 \%$. Various analytical evaluations related to accuracy targets have been published in the literature [12-14]. Since we are members of the KBUDEK EXternal Quality Control Program, we elected to use KBUDEK evaluation samples in our accuracy study. The acceptable accuracy values of the Randox International Quality Assessment Scheme (RIQAS) and the Vitamin D External Quality Assessment Scheme (DEQAS) have been defined as 30.2\% and 25\% [15]. The KBUDEK 2018 acceptable accuracy value in the $13^{\text {th }}$ report period for $25(\mathrm{OH}) \mathrm{D}$ was $<25 \%$, and both methods examined in our study met that criterion. Positive bias was found in the third and fourth KBUDEK samples using both the Architect and Access analyzers, and negative bias was found in the fifth sample. Both methods in our study demonstrated very high accuracy.

The results of our linearity study revealed a linear range similar to that defined by the manufacturers. In our study, the fact that patient samples did not contain high $25(\mathrm{OH}) \mathrm{D}$ values was due to the absence of high $25(\mathrm{OH}) \mathrm{D}$ levels in the samples 
brought to the hospital laboratory, which may be considered as a limiting factor of our study.

The LoB, LoD, and LoQ results were close to the statements provided by the manufacturers and the findings were consistent. We found an LoB of $1.55 \mathrm{ng} / \mathrm{mL}$, an LoD 2.28 of $\mathrm{ng} / \mathrm{mL}$, and an LoQ of $4.0 \mathrm{ng} / \mathrm{mL}$ with the Access products. Madenci et al. [3] reported an LoB value of $1.92 \mathrm{nmol} / \mathrm{L}(0.076 \mathrm{ng} / \mathrm{mL})$, an LoD of $5.67 \mathrm{nmol} / \mathrm{L}(0.226 \mathrm{ng} / \mathrm{mL})$, and an LoQ of 8.84 $\mathrm{nmol} / \mathrm{L}(0.353 \mathrm{ng} / \mathrm{mL})$ for the Access 2 system. Various analytical evaluations related to CV and bias have been published in previous studies in the literature [12-14]. Cavalier et al. [16] reported within-run and between-run CV values of 10.9-13.3\% and $1.7-2.1 \%$, respectively, for concentrations of $5.1 \mathrm{ng} / \mathrm{mL}$ and $37.8 \mathrm{ng} / \mathrm{mL}$ for an earlier Architect 25(OH)D kit (ref: 3L52), and they reported within-run and between-run CV values of $5.2-5.6 \%$ and $1.7-2.6 \%$, respectively, for concentrations of 5.1 $\mathrm{ng} / \mathrm{mL}$ and $37.8 \mathrm{ng} / \mathrm{mL}$ for the new Architect 25(OH)D kit (ref: 5P02). They found a correlation coefficient value of 0.78 (intercept: $0.62[-1.4,2.0]$; slope: $0.91[0.82,0.99])$ for the earlier Architect $25(\mathrm{OH}) \mathrm{D}$ kit compared with reference LC-MS/MS values, and they reported a correlation coefficient value of 0.95 (intercept: $-0.9[-2.1,0.0]$; slope: $0.91[0.88,0.96])$ for the new Architect 25(OH)D kit. Stockl et al. [17] examined within-run and between-run CV\% values of the Siemens Advia Centaur Vitamin D Total test (Siemens Healthcare Diagnostics, East Walpole, MA, USA) at concentrations of $132 \pm 13.6 \mathrm{nmol} / \mathrm{L}$ $(5.28 \pm 0.544 \mathrm{ng} / \mathrm{mL})$ and $338 \pm 31.1 \mathrm{nmol} / \mathrm{L}(13.52 \pm 1.244 \mathrm{ng} / \mathrm{mL})$ and reported findings of $10.3-9.2 \%$ and $11-5.1 \%$, respectively. Within-run and between-run CV\% values of the Roche Elecsys Vitamin D Total test (Roche Diagnostics, Mannheim, Germany) at concentrations of $14.0 \pm 0.2 \mathrm{nmol} / \mathrm{L}(0.56 \pm 0.008 \mathrm{ng} /$ $\mathrm{mL})$ and $33.6 \pm 0.5 \mathrm{nmol} / \mathrm{L}(1.344 \pm 0.02 \mathrm{ng} / \mathrm{mL})$ were found to be $1.4-1.5 \%$ and $25.2-19.6 \%$, respectively [18]. Madenci et al. found that the coherence and bias\% value of the Access $25(\mathrm{OH}) \mathrm{D}$ test was 0.941 (intercept: 0.420 [-1.12, 1.76]; slope: $0.878(0.819,0.949])$ and $-8.6 \%$, respectively, compared with LC-MS/MS results, and the coherent correlation coefficient and bias\% value of the Access $25(\mathrm{OH}) \mathrm{D}$ test was 0.854 (intercept: 0.697 [-0.687, 2.031]; slope: $0.748[0.698,0.801])$ and $-19.2 \%$, respectively. In that study, the total $C V$ values for the Beckman Coulter DXL800 System (Beckman Coulter, Inc., Brea, CA, USA) and the Access 2 System at low and high concentrations were 8.9-9.2\% and 8.1-7.7\%, respectively [3]. Stockl et al. recommended a rigorous analytical precision value goal for serum/ plasma $25(\mathrm{OH}) \mathrm{D}$ of $\mathrm{CV} \%<10 \%$ in routine measurements and $<5 \%$ for reference measurements. In that study, the recommended mean bias value for serum/plasma $25(\mathrm{OH})$ D was $\leq 5 \%$ in routine measurements using the most stringent conditions and $\leq 1.7 \%$ for reference measurements. Özcan et al. [11] reported within-run, between-run, between-day, and total CV\% values for the Beckman Coulter DXL800 System and Access 2 $25(\mathrm{OH}) \mathrm{D}$ Total tests at concentrations of $28 \mathrm{ng} / \mathrm{mL}$ and 64.3 $\mathrm{ng} / \mathrm{mL}$ of $5.6-5.5 \%, 3.2-8.5 \%$, and $4.6-2.6 \%, 3.0-6.1 \%$, respectively, in routine clinical measurements. They found an $r$ value and mean bias value of 0.944 (intercept: -0.089 [-1.087, 0.910]; slope: $0.951[0.916,0.985])$ and $-2.9 \%$, respectively, compared with LC-MS/MS. In our study, within-run, between-run, and between-day CV\% values of the new Architect 25(OH)D test at the concentrations of $14.35 \pm 0.35 \mathrm{ng} / \mathrm{mL}, 21.25 \pm 4.25 \mathrm{ng} / \mathrm{mL}$, and $34.55 \pm 6.95 \mathrm{ng} / \mathrm{mL}$ in the Architect I2000SR System were 3.1-2.4-1.7\%, 1.7-2.1-2.1\%, and 2.8-3.0-3.5\%, respectively, and within-run, between-run, and between-day $\mathrm{CV} \%$ values of the Beckman Coulter Access 25(OH)D Total test at concentrations of $21.5 \pm 6.5 \mathrm{ng} / \mathrm{mL}$ and $45.0 \pm 10 \mathrm{ng} / \mathrm{mL}$ in the Access2 System were $6.7-6.1 \%$ and $13.9-5.6 \%$, respectively. In our study, the CV\% results for the Access analyzer between-run were $<13.9 \%$ and $<8.4 \%$ between-day, which was similar to the results reported by Stockl et al. The CV\% of $<3.54 \%$ determined for the Architect system was well below the $\leq 10 \%$ precision criterion described by Stockl et al.

\section{Conclusion}

In conclusion, our study results confirmed that the commonly used Architect and Access 25(OH)D kits and analyzers demonstrated acceptable analytical performance. In particular because $25(\mathrm{OH}) \mathrm{D}$ testing is becoming widespread, providing interlaboratory results might be useful. Additional comparison studies will also be helpful to create harmonization.

\section{Conflict of interest: There is no conflict of interest.}

Ethics Committee Approval: The clinical research ethics committee of our region (Bolu Abant Izzet Baysal University Clinical Research Ethics Committee) approved this study on March 13, 2019 (no: 2019/97).

Financial Disclosure: The authors declared that this study has received no financial support.

Peer-review: Externally peer-reviewed.

Authorship contributions: Concept - G.B., O.M.Y.; Design - G.B., O.M.Y.; Supervision - G.B., O.M.Y.; Funding - R.N.Y., H.O., O.M.Y.; Materials - R.N.Y., H.O., O.M.Y.; Data collection \&/or processing R.N.Y., H.O., O.M.Y.; Analysis and/or interpretation - R.N.Y., H.O., O.M.Y.; Literature search - G.B., O.M.Y., R.N.Y., H.O.; Writing - G.B., O.M.Y.; Critical review - G.B., O.M.Y., R.N.Y., H.O.

\section{References}

1. Leino A, Turpeinen $U$, Koskinen P. Automated measurement of $25-\mathrm{OH}$ vitamin D3 on the Roche Modular E170 analyzer. Clin Chem 2008;54:2059-62. [CrossRef]

2. Hutchinson K, Healy M, Crowley V, Louw M, Rochev Y. Verification of Abbott 25-OH-vitamin D assay on the architect system. Pract Lab Med 2017;7:27-35. [CrossRef]

3. Madenci ÖÇ, Orçun A, Yildiz Z, Sirmali R, Tunçbilek N, Yücel $\mathrm{N}$, et al. Evaluation of new Beckman Coulter 25(OH) Vitamin $\mathrm{D}$ assay and potential improvement of clinical interpretation. Biochem Med (Zagreb) 2017;27:332-41. [CrossRef] 
4. Holick MF. Vitamin D status: measurement, interpretation, and clinical application. Ann Epidemiol 2009;19:73-8. [CrossRef]

5. Carter GD. Accuracy of 25-hydroxyvitamin D assays: confronting the issues. Curr Drug Targets 2011;12:19-28. [CrossRef]

6. Lai JK, Lucas RM, Banks E, Ponsonby AL; Ausimmune Investigator Group. Variability in vitamin D assays impairs clinical assessment of vitamin D status. Intern Med J 2012;42:43-50.

7. Hollis BW. Editorial: The determination of circulating 25-hydroxyvitamin D: no easy task. J Clin Endocrinol Metab 2004;89:3149-51. [CrossRef]

8. Sempos CT, Vesper HW, Phinney KW, Thienpont LM, Coates PM; Vitamin D Standardization Program (VDSP). Vitamin D status as an international issue: national surveys and the problem of standardization. Scand J Clin Lab Invest Suppl 2012;243:32-40.

9. Wallace AM, Gibson S, de la Hunty A, Lamberg-Allardt C, Ashwell $M$. Measurement of 25-hydroxyvitamin $D$ in the clinical laboratory: current procedures, performance characteristics and limitations. Steroids 2010;75:477-88. [CrossRef]

10. Schoenmakers $\mathrm{CH}$, Naus AJ, Vermeer HJ, van Loon D, Steen G. Practical application of Sigma Metrics QC procedures in clinical chemistry. Clin Chem Lab Med 2011;49:1837-43. [CrossRef]

11. Ozcan N, Ucar F, Arzuhal AE, Bulut E, Ozturk A, Taslipinar Yavuz $M$, et al. Evaluation of the analytical performance of Unicel DXI 800 for the Total $25(\mathrm{OH})$ Vitamin D measurements. Clin Biochem 2016;49:486-91. [CrossRef]
12. Janssen MJ, Wielders JP, Bekker CC, Boesten LS, Buijs MM, Heijboer AC, et al. Multicenter comparison study of current methods to measure 25-hydroxyvitamin D in serum. Steroids 2012;77:1366-72. [CrossRef]

13. Farrell CJ, Martin S, McWhinney B, Straub I, Williams P, Herrmann M. State-of-the-art vitamin D assays: a comparison of automated immunoassays with liquid chromatography-tandem mass spectrometry methods. Clin Chem 2012;58:531-42.

14. Binkley N, Krueger D, Cowgill CS, Plum L, Lake E, Hansen KE, et al. Assay variation confounds the diagnosis of hypovitaminosis D: a call for standardization. J Clin Endocrinol Metab 2004;89:3152-7. [CrossRef]

15. Binkley N, Krueger DC, Morgan S, Wiebe D. Current status of clinical 25-hydroxyvitamin D measurement: an assessment of between-laboratory agreement. Clin Chim Acta 2010;411:1976-82. [CrossRef]

16. Cavalier E, Lukas P, Bekaert AC, Carlisi A, Le Goff C, Delanaye $P$, et al. Analytical and clinical validation of the new Abbot Architect 25(OH)D assay: fit for purpose? Clin Chem Lab Med 2017;55:378-84. [CrossRef]

17. StöckID, Sluss PM, Thienpont LM. Specifications for trueness and precision of a reference measurement system for serum/plasma 25-hydroxyvitamin D analysis. Clin Chim Acta 2009;408:8-13.

18. Dai P, Harada Y, Takamatsu T. Highly efficient direct conversion of human fibroblasts to neuronal cells by chemical compounds. J Clin Biochem Nutr 2015;56:166-70. [CrossRef] 